\title{
Bir Üniversite Hastanesinde Çalışan Hemşirelerin Hastane Afet ve Acil Durum Planları ile İgili Görüşlerinin İncelenmesi $\infty$
}

\author{
Aysun IYTEMÜR ${ }^{1}$, Sıdıka TEKELI YEŞiL ${ }^{2}$
}

\section{öz}

Amaç: Bir üniversite hastanesinde çalışan hemşirelerin Hastane Afet ve Acil Durum Planlarına ilişkin görüşlerini incelemektir.

Gereç ve Yöntem: Tanımlayııı tipte bir araştırmadır. Araştırmanın evrenini, bir üniversite hastanesinde çalışan hemşireler oluşturmaktadır. Veriler Nisan - Temmuz 2016 tarihleri arasında 28 soruluk bir anket aracılığı ile toplanmıştır. Çalışmaya 402 hemşire katılmışır. Katılımcıların afet ve acil durum planları hakkındaki görüşleri ile ilişkili olabilecek değişkenleri değerlendirmek için demografik, çalışma geçmişi, afet deneyimi gibi ankette yer alan değişkenler ile çapraz tablolar oluşturulmuştur. İstatistiksel anlamlılık ki kare testi ile değerlendirilmiştir.

Bulgular: Katılımcıların \%70'i afet ve acil durumla ilgili bir eğitime katıldıklarını belirtmişlerdir. Eğitim almadığını belirtenlerin çoğunluğu (\%71) 21-30 yaş grubundadır. Hastane Afet ve Acil Durum Planlarından haberdar olmadığını ifade edenlerin çoğunluğu (\%76) yine 21-30 yaş grubundadır. Hastane Afet ve Acil Durum Tatbikatlarından haberdar olduğunu belirten hemşirelerin $\% 60$ '। meslekte 6-10 yıl çalışma sürelerine sahiplerdir.

Sonuç: Hastane Afet ve Acil Durum Planları konusunda haberi olmadığını ifade edenlerin çoğunluğunu mesleğin ve kurumda çalışmanın ilk yıllarında olan hemşireler oluşturmaktadır. Özellikle mesleğin ve kurumda çalışmanın ilk yıllarındaki hemşirelere, Hastane Afet ve Acil Durum Planları ile ilgili eğitimler ve farkındalık çalışmaları, tatbikatlara dâhil edilme gibi konularda öncelik verilmesi önerilmektedir.

Anahtar kelimeler: Acil durumlar, afet, afet ve acil durum planları, hastane, hemşire

\begin{abstract}
Examining the Opinions of Nurses Working in a University Hospital About Hospital Disaster and Emergency Plans

Aim: The study aim was to examine the opinions of nurses working in a university hospital about Hospital Disaster and Emergency Plans.

Material and Methods: This is a descriptive study. The universe of the research was the nurses working in a university hospital. The data were collected between April and July 2016 through a questionnaire consisting of 28 questions. 402 nurses participated in the study. In order to evaluate the variables that may be related to the participants' views on disaster and emergency plans, crosstables were formed with the variables included in the questionnaire such as demographic, work history, disaster experience. Statistical significance was evaluated by chi-square test.

Results: $70.0 \%$ of the participants stated that they attended a training on disaster and emergency. The majority of those (71\%) who stated that they did not receive training were in the 21-30 age group. The majority of those $(76 \%)$ who stated that they were not aware of the Hospital Disaster and Emergency Plans were also in the $21-30$ age group. $60 \%$ of the nurses who stated that they were aware of Hospital Disaster and Emergency Drills had 6-10 years working experience in the profession.

Conclusion: The majority of those who stated that they were not aware of Hospital Disaster and Emergency Plans were nurses who had few years working experience in the profession and the institution. It is recommended to give priority to nurses who have several years of experience in the profession and the institution, on issues such as trainings and awareness studies on Hospital Disaster and Emergency Plans, and inclusion in drills.

Keywords: Disaster, disaster and emergency plans, emergencies, hospital, nurse
\end{abstract}

${ }^{1}$ Arş.Gör. Yüksek intisas Üniversitesi, Sağlık Bilimleri Fakültesi, Hemşirelik Bölümü, Kadın Hastalıkları ve Doğum Hemşireliği Programı, Ankara, Türkiye, E-mail: aysuniytemur@gmail.com, Tel: +90 535864 7556, ORCID: 0000-0002-5158-3627

2Dr. Öğr. Üyesi Hacettepe Üniversitesi, Halk Sağlığı Enstitüsü; Scientific Consultant, Rheinfelden, Switzerland, E-mail: sidikatekeli@hotmail.com, Tel: +41 61 83131161, ORCID: 0000-0002-7930-3252

Geliş Tarihi: 14 Haziran 2019, Kabul Tarihi: 11 Mayıs 2020

Atıf/Citation: İytemur A., Tekeli Yeșil S. Bir Üniversite Hastanesinde Çalışan Hemşirelerin Hastane Afet ve Acil Durum Planları ile İlgili Görüşlerinin İncelenmesi. Hacettepe Üniversitesi Hemşirelik Fakültesi Dergisi 2020; 7(2): 138-148. DOI: 10.31125/hunhemsire.763162 


\section{Giriş}

Dünyada ve ülkemizde afet ve acil durumlar önemli bir halk sağlığı sorunu olarak karşımıza çıkmaktadır ${ }^{1}$. Doğa (deprem, sel gibi) ve insan kaynaklı (nükleer, santral ve transfer kazaları gibi) tehlikeler tek başlarına afete yol açmamaktadır. Söz konusu tehlikeler ne zaman toplumların yoksulluk, eğitimsizlik, yanlış şehirleşme, vb. zarar görebilirlikleri ile bir araya gelirlerse o zaman afete dönüşmektedirler. Afetler insan sağlığının her üç boyutunu da, bedensel, ruhsal ve sosyal, çeşitli şekillerde etkiler. Beklenmedik sayıda ölüm, yaralanma veya hastalık; sağlık altyapısının tahrip olması ve rutin sağlık hizmetlerinin kesintiye uğraması; bulaşıcı hastalıklar veya yiyecek sıkıntısına yol açabilecek şekilde çevrenin etkilenmesi; ruh sağlığı problemleri ve spontan veya organize olmuş bir şekilde gelişen göç hareketleri, afetlerin halk sağlığı üzerindeki etkilerinin başlıcalarıdır ${ }^{2-4}$.

Afet ve acil durumlar her sektörü etkilese de, sağlık sektörü en çok etkilenenler arasındadır ${ }^{3,5-6}$. Sağlık sektörünün en önemli parçalarından biri hastanelerdir. Herhangi bir afet durumunda hastaneler, hem afeti yaşayıp hem de afete yanıt verme durumunda kalmaktadırlar. Hastaneler bu özellikleri ile diğer kurumlardan ve iş yerlerinden ayrılır ${ }^{3}$. Hastanelerin afet ve acil durumlara fiziksel ve fonksiyonel olarak hazırlıklı olmaları, afet anında hızlı ve etkin bir şekilde müdahale edebilmeleri ancak Hastane Afet ve Acil Durum Planları (HAP) ile mümkündür 5,7 .

Afetlerle başa çıkmada önemli bir yere sahip olan HAP'lar, afet ve acil durumlara ilişkin riskleri önlemeyi ve azaltmayı, hazırlıklı olmayı ve etkin müdahaleyi amaçlar. Karmaşık bir yapıya sahip olan hastanelerin tehlikeler karşısında zarar görebilirliğini azaltır, personelin, hasta ve hasta yakınlarının can güvenliğini korur ve hastane donanımının zarar görmesini engeller, hastanelerin fonksiyonlarını sürdürmelerini sağlar?.

Hastane Afet ve Acil Durum Planları hastaneye özgü olup, Sağlık Bakanlığı tarafından geliştirilen kılavuz ile standart bir çerçevede hazırlanır. HAP'lar sadece müdahale aşamasında değil afet öncesi, sırası ve sonrası dönemde yapılması gerekenlerin ne zaman, nasıl ve kimin tarafından yapılması gerektiğini, görev alan personellerin sorumluluklarını açıkça tanımlayan sistematik planlardır ${ }^{7}$.

Hastaneler birçok farklı branşta sağlık personelini barındıır. Hemşireler ise hastane personelinin büyük çoğunluğunu oluşturduğu gibi sağlık hizmetlerinin sunumunda da önemli bir yere sahiptir. Hemşirelerin sayıca fazla olmasının yanı sıra, sağlık sisteminin her alanında hizmet vermeleri, hastanelerin tüm birimlerinde görev almaları ve aldıkları eğitim gereği sağlık bilimleri dışında sosyoloji, iletişim gibi konularda da bilgi ve becerilere sahip olmaları bu konudaki etkinliklerini arttırmaktadır. Bu durum hemşirelere afet ve acil durumlarda da önemli roller yüklemektedir ${ }^{8,9}$. Ancak, literatüre baktığımızda hemşirelerin HAP hakkında görüş, bilgi ya da tutumlarına ilişkin sınırlı sayıda çalışma bulunmaktadır ${ }^{10-11}$. Bu çalışmaların bazıları hastanelerin tüm personel grubu ile yapılan çalışmalardır. Yalnızca hemşireler ile yapılan çalışmalar ise daha sınırlı sayıdadır ${ }^{12-}$ 14.
Fung ve diğerleri (2008) Hong Kong Üniversitesinde yüksek lisans programına katılan hemşireler ile yaptıkları çalışmada, katılımcıların \%61.0'inin HAP'dan haberdar olduğu sonucuna ulaşmışlardır ${ }^{15}$.

Al Thobaity ve diğerleri (2014) tarafından Suudi Arabistan'da kamu ve askeri hastanelerinin karşılaştırıldığı çalışmada, acil durum ve afetlere yanıt sırasında hemşirelerin önemli rollere sahip oldukları üzerine durulmuştur. Toplam 600 hemşire ile yapılan bu çalışmada, askeri hastanede çalışan hemşirelerin kamu hastanesinde çalışan hemşirelere göre afetle ilgili bilgi düzeylerinin daha yüksek olduğu sonucuna ulaşmışlardır ${ }^{16}$.

Elazeem ve diğerleri (2011) Mısır'da bir üniversite hastanesinde 56 doktor, 22 başhemşire, 73 hemşire, 70 sağlık teknikeri, 99 idari çalışan, 80 temizlik personeli olmak üzere toplamda 400 sağıı personeli ile yaptıkları çalışmada, personelin hastane iç afetleri ile ilgili farkındalıklarının tüm personel gruplarında düşük olduğu sonucuna ulaşmışlardır. Aynı zamanda afet ve acil durum ile ilgili tatbikatların ve afet ve acil durum planları ile ilgili eğitimlerin ise istenilen düzeyde olmadığı belirtilmiştir ${ }^{17}$.

Vatan ve Salur'un (2010) İzmir'de bulunan 39 hastanede görevli 71 yönetici hemşire ile yaptıkları çalışmada, hemşirelerin büyük bir çoğunluğu (\%83.4) HAP'dan haberdar olduklarını, \%58.3'ü HAP'da görevinin olduğunu, \%41.7'si ise görevinin olmadığını belirtmiştir. Katılımcıların \%46.7'si afet senaryo uygulamalarının yapıldığını ifade etmiştir ${ }^{18}$.

Yurdakul ve diğerlerinin (2012) Kocaeli Derince Eğitim ve Araştırma Hastanesi yönetimi ve personeline yönelik yaptıkları çalışmada, çalışmaya katılan 164 personelin yarıdan fazlası (\%64.0) çalıştığı hastanenin bir afet planına sahip olduğunu, bu planın var olduğunu ifade edenlerin \%66.3'ünün ise afet-risk analizinin yapılmadığını veya bu konuda bilgilerinin olmadığını belirtmişlerdir. Çalışmaya katılan ve mevcut bir afet planı olduğunu düşünen hastane personelinin \%64.0'ü de bu planı inceleme fırsatlarının olmadığını ifade etmişlerdir ${ }^{19}$.

Çakmak ve diğerlerinin (2010) Kocaeli ili 112 acil yardım hizmetlerinde görev yapan sağlık personeli (hekim, hemşire, sağlık memuru, ebe, acil tıbbi teknisyen) ile yaptıkları çalışmada, 92 katılımcının \%76.1'i çalıştıkları kurumun bir afet planının olduğunu, \%51.1'i afet durumlarında resmi olarak görevlendirildiklerini, \%42.2'si ise herhangi bir afet durumunda görev ve sorumluluklarını bildiklerini belirtmişlerdir ${ }^{20}$.

Türk Tabipler Birliği'nin (2009) Türkiye'de yataklı tedavi kurumlarında çalışan uzman ve pratisyen hekimler ile online anket uygulayarak yaptığı bir çalışmasında ise, araştırmaya katılan doktorların ( $n=449)$ \%36.5'i HAP'dan haberdar olduğunu, \%16.3'ü Hastane Afet Planı Eğitimi aldığını, \%13.1'i Hastane Afet Planı Tatbikatından haberdar olduğunu, \%10.5'i çalıştıkları hastanede kitlesel yaralanma vakaları için hazırlık planı yapıldığını, \%9.6'sının çalıştıkları hastanenin olağandışı bir duruma hazır olduğunu ifade etmiştir ${ }^{21}$.

Araştırmanın yapıldığı üniversite hastanesi, farklı alanda bir çok branşı barından ülkemizin önde gelen hastanelerindendir. Sağlık alanındaki öncü konumu 
üniversite hastanesine ülkemizde ve Ankara'da yaşanabilecek afet ve acil durumlara müdahale konusunda bir çok sorumluluk yüklemektedir. Ayrıca iç afet ve acil durumlara karşı her zaman hazırlıklı olması gerekmektedir. Üniversite hastanesinin HAP konusunda öncü bir konumu vardır22. Hem bu özellikleri hem de geniş ve çeşitli fiziki ve fonksiyonel yapısı bir çok farklı serviste çalışan hemşirenin afet ve acil durum planları hakkındaki görüşlerini değerlendirebilme olanağı sağlamaktadır. Yukarıda örnekleri yer alan çalışmaların birçoğu farklı personel gruplarının yer aldığı veya sınırlı sayıda katılımcı ile yapılan çalışmalardır. Rutin sağlık hizmetlerinde olduğu gibi afet ve acil durumlarda da önemli görev ve sorumluluklar üstlenen hemşirelerin bu konudaki görüşlerinin değerlendirilerek önerilerde bulunulması hem genel olarak HAP'lara hem üniversite hastanesinin HAP'ına önemli katkılarda bulunacaktır.

Buradan yola çıkarak söz konusu çalışmada üniversite hastanesinde çalışan hemşirelerin HAP'a ilişkin görüşlerinin incelenmesi amaçlanmıştır.

\section{Araştırmanın Amacı}

Çalışma, bir üniversite hastanesinde çalışan hemşirelerin HAP'a ilişkin görüşlerini incelemek amaçlı yapılmıştır.

\section{GEREÇ ve YÖNTEM}

\section{Araştırmanın Türü}

Çalışma, tanımlayıcı tipte bir araştırmadır.

\section{Araştırmanın Evreni ve Örneklemi}

Çalışma evrenini, bir üniversite hastanesinde çalışan hemşireler oluşturmaktadır. Araştırmada örneklem seçim yöntemi uygulanmamış olup, Nisan-Temmuz 2016 tarihleri arasında ulaşılabilen ve araştırmaya katılmayı kabul eden 402 hemşire çalışma kapsamına alınmıştır.

\section{Veri Toplama Araçları}

Veri toplama aracı olarak, araştırmacıların deneyimleri ve literatür bilgisi doğrultusunda araştırmacılar tarafından hazırlanan anket formu kullanılmıştı ${ }^{8-17-18-20}$. Veri toplama aracı olarak kullanılan anket 28 sorudan oluşmaktadır. Anketin ilk bölümde yer alan 8 soru, katılımcıların sosyodemografik özelliklerine ve eğitim bilgilerine ilişkin sorulardır. Sonraki bölümdeki yer alan 8 soru, katılımcıların afet ve acil durumlarla ilgili deneyimlerini, son bölümde yer alan 12 soru ise HAP ile ilgili görüş ve bilgilerini öğrenmek amacıyla hazırlanmış sorulardır.

\section{Verilerin Toplanması}

Araştırma Nisan-Temmuz 2016 tarihleri arasında gerçekleştirilmiştir. Veri toplamak üzere araştırmanın yapıldığı hastanenin bütün bölüm, poliklinik ve servislerine ziyarette bulunulmuş, birim sorumlularının birimde çalışan hemşire sayıları hakkında verdiği bilgiler doğrultusunda anket bırakılmıştır. Anketler 3 gün sonra toplanmıştır. Gerekli durumlarda 2 defa daha anketleri toplamak için ziyaretlerde bulunulmuştur. Ancak bazı birim sorumluları yoğun çalışma temposu gerekçesi ile birim hemşirelerine dağıtılmak üzere ancak sınırlı sayıda anket kabul etmiştir.

Bırakılan anketlerden 402 tanesi doldurularak araştırmacıya teslim edilmiştir. Çalışmanın yapıldığı üniversite hastanesinde 2016 yılında toplam 1100 hemşire çalışmaktadır ${ }^{23}$. Üniversite hastanesinde çalışan hemşirelerin \%38.2'sine ulaşılabilmiştir.

\section{Verilerin Değerlendirilmesi}

Veri girişi ve analizinde SPSS 15.0 İstatistik Programı kullanılmıştır. Araştırma kapsamında toplanan verilerin frekans dağılımlarına bakılmıştır. Tanımlayıcı bilgilerin sunumu için sıklık dağılımları, ortalama, ortanca, standart sapma, minimum ve maksimum değerleri verilmiştir. Olası ilişkili faktörleri tespit etmek için çapraz tablolar oluşturularak pearson ki-kare anlamlılık testi uygulanmıştır. Olası ilişkileri değerlendirmek için cinsiyet, yaş, eğitim, hemşire olarak çalışma süresi, çalıştığı hastane, çalıştığı bölüm, poliklinik ya da servis, çalıştığı pozisyon, üniversite hastanesinde çalışma süresi, afet ya da acil durum ile ilgili eğitim alma, afet ya da acil durumla ilgili görevli olarak çalışma, afet ya da acil durum ile ilgili sivil toplum kuruluşuna üyelik değişkenleri ile HAP değişkenleri (HAP'dan haberdar olma, HAP'daki görevini bilme, Hastane afet ve acil durum tatbikatlarından haberdar olma, Hastanenin afet ve acil duruma hazır olup olmadığını düşünme ve HAP'ın gerekli olup olmadığını düşünme değişkenleri) arasındaki ilişki çapraz tablolar oluşturularak değerlendirilmiştir.

\section{Araştırmanın Etik Boyutu}

Araştırmaya başlamadan önce üniversitenin Girişimsel Olmayan Klinik Araştırmalar Etik Kurulu'ndan etik kurul izni (Karar No: GO 16/54-06) ve araştırmanın yapıldığı hastanenin yönetimlerinden (Sayı: 20481383-970/3559), (Sayı: 62443999-020/352) (Sayı: 75967797-804.01/3817) (Sayı: 63305009-771.08/567) kurum izinleri alınmıştır. Anket uygulaması için anket formunun ön bölümünde yer alan bilgilendirme ve onam formu ile çalışmaya katılan hemşirelerden onam alınmış, araştırma ve yayın sürecinde Helsinki Deklerasyonu Prensipleri'ne, araştırma ve yayın etiğine uygun hareket edilmiştir.

\section{Araştırmanın Sınırlılıkları}

Veri toplama araçlarının uygulanması başığında da belirtildiği gibi bazı bölüm, poliklinik ya da servislerde toplam hemşire sayısı kadar değil, birim sorumlularının izin verdiği sayıda anket bırakılabilmiştir. Bu durum çalışmaya katılmak isteyebilecek bazı hemşirelerin katılımını sınırlandırmış olabilir.

\section{BULGULAR}

Katılımcıların büyük bir çoğunluğunu (\%95.3, $n=383$ ) kadınlar oluşturmaktadır. Yaş ortalamaları ise $30^{\prime}$ dur (en düşük 21, en yüksek 61 Ortanca değer=30). Hemşirelerin \%96.5'i ( $n=388$ ) sağlık meslek lisesi veya lisans mezunu, $\% 2.2^{\prime}$ si ise $(n=9)$ yüksek lisans mezunudur. Hemşire olarak çalışma süreleri, minumum 2 ay, maksimum 370 aydır (Ortalama değer $=90 \pm 71.9$, Ortanca değer $=72$ ). Katılımcıların \%46.0'sı ( $n=185$ ) 0-5 yıl arası çalışma süresine sahiptir. Anket uygulaması esnasında hemşirelerin büyük bir kısmını (\%53.7, $n=216$ ) erişkin hastanesinde çalışan hemşireler oluşturmuştur. Araştırmaya katılan hemşirelerin \%92.8'ini ( $n=373)$ bölüm, poliklinik ya da servis hemşireleri oluşturmaktadır. Katılımcılar, üniversite hastanesinde çalışma sürelerini minimum 2 ay, maksimum ise 370 ay olarak belirtmişlerdir (Ortalama değer $=82 \pm 70.9$, Ortanca 
değer=68). Araştırmaya katılan hemşirelerin \%81.3'ü ( $n=327) 25$ ay ve üzeri çalışma süresine sahiplerdir. Katılımcıların sosyo-demografik özellikleri Tablo 1'de sunulmaktadır.

Tablo 1. Üniversite Hastanesinde Çalışan ve Araştırmaya Katılan Hemşirelerin Bazı Sosyo-Demografik Özellikleri $(n=402)$

\begin{tabular}{|l|l|l|}
\hline Sosyo-demografik özellik & $\mathbf{n}$ & $\%$ \\
\hline Cinsiyet & & \\
\hline Kadın & 383 & 95.3 \\
\hline Erkek & 19 & 4.7 \\
\hline Toplam & 402 & 100.0 \\
\hline Yaş & & \\
\hline $21-30$ & 222 & 55.2 \\
\hline $31-61$ & 177 & 44.0 \\
\hline Toplam & 399 & 99.2 \\
\hline Eğitim & & \\
\hline Sağlık Meslek Lisesi ve Lisans Mezunu & 388 & 96.5 \\
\hline Yüksek Lisans Mezunu & 9 & 2.2 \\
\hline Toplam & 397 & 98.7 \\
\hline Hemşire olarak çalışma süresi & & \\
\hline $0-5$ yıl & 185 & 46.0 \\
\hline $6-10$ yıl & 145 & 36.1 \\
\hline 11 yıl ve üzeri & 71 & 17.7 \\
\hline Toplam & 401 & 99.8 \\
\hline Çalışı̆ı hastane & & \\
\hline Erişkin hastanesi & 216 & 53.8 \\
\hline Onkoloji hastanesi & 68 & 16.9 \\
\hline Çocuk hastanesi & 103 & 25.6 \\
\hline Diğer hastane birimi & 10 & 2.5 \\
\hline Diş hekimliği & 5 & 1.2 \\
\hline Toplam & 402 & 100 \\
\hline Çalıştığı bölüm, poliklinik ya da servis & & \\
\hline Acil servis & 30 & 7.5 \\
\hline Yoğun bakım ünitesi & 51 & 12.7 \\
\hline Ameliyathane & 12 & 3.0 \\
\hline Diğer & 309 & 76.8 \\
\hline Toplam & 402 & 100 \\
\hline Çalıştığı pozisyon & & \\
\hline Başhemşire & 29 & 7.2 \\
\hline Bölüm, poliklinik ya da servis hemşiresi & 373 & 92.8 \\
\hline Toplam & 402 & 100.0 \\
\hline Üniversite hastanesinde hemşire olarak çalışma süresi \\
\hline $0-24$ ay & 75 & 18.7 \\
\hline 25 ay ve üzeri & 327 & 81.3 \\
\hline Toplam & 402 & 100.0 \\
\hline
\end{tabular}

*Toplam sayıdaki farklılıklar her bir satırdaki kayıp değerden kaynaklanmaktadır.

Ankete katılan hemşirelerin \%70.9'i ( $n=285)$ "Afet ya da acil durumla ilgili herhangi bir eğitim aldınız mı?" sorusuna evet yanıtını vermiştir. Araştırmaya katılan hemşirelerden çok azı daha önce afet ya da acil durumda görevli olarak çalıştığını belirtmiştir (\%3.7, n=15). Katılımcıların çok az bir kısmı $(\% 1.7, n=7)$ afet ya da acil durumla ilgili gönüllü sivil toplum kuruluşuna üye olduğunu belirtmiştir. Katılımcıların yarıdan fazlası (\%58.4, n=234) HAP'dan haberdar olduklarını ifade etmiştir. Ankete katılan hemşirelerin \%48.8'i ( $n=117)$ "HAP'daki görevinizi biliyor musunuz?" sorusuna evet yanıtını vermiştir. Katılımcılardan yarıdan fazlası (\%54.8, $\mathrm{n}=132$ ) afet ve acil durum tatbikatlarından haberdar olduklarını söylemiştir. Katılımcıların \%60.5'i ( $n=242)$ çalıştığı hastanenin afet ve acil durumlara hazır olmadığını ya da bilmediğini ifade etmiştir. Katılımcıların büyük çoğunluğu (\%98.0, n=391) HAP'ın gerekli olduğunu ifade etmişlerdir (Tablo 2).

Tablo 2. Üniversite Hastanesinde Çalışan ve Araştırmaya Katılan Hemşirelerin Afet ve Acil Durum ile ilgili Anket Sorularına Verdikleri Yanıtların Dağılımı ( $n=402)$

\begin{tabular}{|l|l|l|}
\hline Afet ve acil durum ile ilgili bazı özellikler & $\mathbf{n}$ & $\%$ \\
\hline Afet ve acil durumla ilgili eğitim alma & & \\
\hline Evet & 285 & 70.9 \\
\hline Hayır & 117 & 29.1 \\
\hline Toplam & 402 & 100.0 \\
\hline Afet ya da acil durumda görevli olarak çalışma & & \\
\hline Evet & 15 & 3.7 \\
\hline Hayır & 386 & 96.3 \\
\hline Toplam & 401 & 100.0 \\
\hline Afet ya &
\end{tabular}

Afet ya da acil durumla ilgili gönüllü sivil toplum kuruluşuna üyelik

\begin{tabular}{|l|l|l|}
\hline Var & 7 & 1.7 \\
\hline Yok & 394 & 98.3 \\
\hline Toplam Acil Durum Planları'ndan & 401 & 100.0 \\
\hline $\begin{array}{l}\text { Hastane Afet ve } \\
\text { haberdar olma }\end{array}$ & \\
\hline Var & 234 & 58.4 \\
\hline Yok ya da bilmiyorum & 167 & 41.6 \\
\hline Toplam & 401 & 100.0 \\
\hline $\begin{array}{l}\text { Hastane Afet ve Acil Durum Planları'ndaki } \\
\text { görevini bilme }\end{array}$ & & \\
\hline Evet & 117 & 48.8 \\
\hline Hayır & 123 & 51.3 \\
\hline Toplam & 240 & 100.0 \\
\hline $\begin{array}{l}\text { Afet ve acil durum tatbikatlarından } \\
\text { haberdar olma }\end{array}$ & \multicolumn{2}{|l|}{} \\
\hline Evet & 132 & 54.8 \\
\hline Hayır & 109 & 45.2 \\
\hline Toplam & 241 & 100.0 \\
\hline $\begin{array}{l}\text { Çalıştığı hastanenin afet ve acil duruma hazır } \\
\text { olup olmadığını düşünme }\end{array}$ & \multicolumn{2}{|l|}{} \\
\hline Evet & 158 & 39.5 \\
\hline Hayır ya da bilmiyorum & 242 & 60.5 \\
\hline Toplam & 400 & 100.0 \\
\hline $\begin{array}{l}\text { Hastane Afet ve Acil Durum Planları'nın gerekli olup olmadığını } \\
\text { düşünme }\end{array}$ & 391 & 98.0 \\
\hline Evet & 8 & 2.0 \\
\hline Hayır & 399 & 100.0 \\
\hline Toplam & \multicolumn{2}{|l}{} \\
\hline \multicolumn{2}{|l|}{} \\
\hline
\end{tabular}

Oluşturulan çapraz tablolarda istatistiksel olarak anlamlı ilişki çıkan değişkenler Tablo 3'de yer almaktadır.

Yaş, hemşire olarak çalışma süresi ve üniversite hastanesinde çalışma süresi ile afet ve acil durumla ilgili eğitim alma arasında istatistiksel olarak anlamlı ilişki bulunmuştur (sırasıyla: $p<0.001, p=0.001, p<0.001$ ). Ankete katılan hemşirelerin büyük bir çoğunluğu $(\% 70.9, n=285)$ afet ya da acil durum ile ilgili eğitim aldıklarını belirtmişlerdir. Afet ve acil durum ile ilgili eğitim almadığını belirtenlerin \%71.5'ini ( $n=83) 30$ yaşın altında olan, $\% 60.7$ 'sini $(n=71)$ mesleğinin ilk beş yılında olan hemşireler oluşturmaktadır. Eğitim aldığını belirtenlerin \%75.8'ini $(n=248)$ üniversite hastanesinde 25 ay ve yukarısı çalışanlar oluşturmaktadır.

Çalıştığı pozisyon ve üniversite hastanesinde çalışma süresi ile afet ya da acil durumda görevli olarak çalışma arasında istatistiksel olarak anlamlı ilişki bulunmuştur (sırasıyla: 
$\mathrm{p}<0.001, \mathrm{p}<0.001)$. Ankete katılan hemşirelerin \%3.7'si $(n=15)$ afet ya da acil durum da görevli olarak çalıştıklarını belirtmişlerdir. Başhemşirelerin \%17.2'si, bölüm, poliklinik ya da servis hemşirelerinin ise \%2.7'si afet ya da acil durumda görevli olarak çalışmıştır $(p<0.001)$. Afet ya da acil durum yaşayan hemşirelerin \%10.1'i $(n=10)$ böyle bir durumu yaşamayan hemşirelerinse $\% 1.7$ 'si $(n=5)$ afet ya da acil durumda görevli olarak çalışmıştır $(p<0.001)$.

Araştırmaya katılan hemşirelerin HAP'a yönelik ifade ve görüşleri ile istatistiksel olarak anlamlı ilişki gösteren değişkenler ise şöyledir.

Araştırmaya katılan hemşirelerin \%57.8'i ( $n=231)$ HAP'dan haberdar olduklarını belirtirken, \%42.0'si ( $n=167)$ haberdar olmadığını belirtmiştir.

HAP'dan haberi olmadığını ya da bilmediğini ifade eden hemşirelerin \%76.0'sı ( $n=127$ ) 21-30 yaş grubu aralığındadır. Yaş ile HAP'dan haberdar olma arasında istatistiksel olarak anlamlı bir ilişki bulunmuştur $(p<0.001)$.

Hemşire olarak çalışma süresi ile HAP'dan haberdar olma arasında istatistiksel olarak anlamlı bir ilişki bulunmuştur. HAP'dan haberdar olmayan 166 katılımcının \%66.3'ü ( $n=110) 5$ yıldan az süredir çalışmaktadır.

Katılımcılardan afet ya da acil durum yaşadığını ifade edenlerin \%76.8' $i \quad(n=76)$, böyle bir durumu yaşamayanlarınsa \%52.3'ü $(n=158)$ hastanenin afet ve acil durum planlarından haberdar olduğunu belirtmiştir $(p<0.001)$.

HAP'daki görevini bilme ile istatistiksel olarak ilişkili olan değişkenler hem hemşire olarak hem de üniversite hastanesindeki çalışma süreleridir (sırasıyla: $p=0.007$, $\mathrm{p}=0.028$ ).

HAP'daki görevini bildiğini ifade eden hemşirelerin hemşire olarak çalışma yılları incelendiğinde, 0-5 yıl aralığında çalışmış olanların \%31.6'sı (n=37) HAP'daki görevini bildiğini ifade etmişlerdir. 11 yıl ve üzeri çalışan hemşirelerin ise \%15.4 ( $n=18)$ görevini bildiğini ifade etmiştir. Bu grup en düşük yüzdeye sahip grubu oluşturmaktadır.

Üniversite hastanesinde 0-24 ay arası çalışanların \%33.3'ü $(n=14), 25$ ay ve yukarısı çalışanların ise \%52.0'si $(n=103)$ HAP'daki görevini bildiğini belirtmektedir $(p=0.028)$.

Afet ve acil durum tatbikatlarından haberdar olma ile istatistiksel olarak ilişkili olan değişkenler ise yine benzer şekilde, yaş, hemşire olarak çalışma süresi ve üniversite hastanesinde çalışma süresidir (sırasıyla: $p=0.001, p<0.001$, $\mathrm{p}<0.001$ ).

21-30 yaş grubu hemşirelerin \%33.1'i $(n=43), 31-61$ yaş grubu aralığında olanların ise \%66.9'u ( $n=87)$ hastane afet ve acil durum tatbikatlarından haberdar olduğunu ifade etmiştir.

Katılımcılardan hastane afet ve acil durum tatbikatlarından haberdar olduğunu belirtenlerin önemli bir kısmının (\%60.4, $\mathrm{n}=64)$ meslekte 6-10 yıl arasında çalışmış olduğu anlaşılmaktadır. Haberdarlık düzeyi en az olan grup $0-5$ yıl arası çalışmış hemşirelerdir (\%22.7, $\mathrm{n}=30$ ).

Hemşirelerden üniversite hastanesinde $0-24$ ay arası çalışanların \%14.0'ü $(n=6), 25$ ay ve yukarısı çalışanların ise $\% 63.6$ 'sı ( $n=126$ ) hastane afet ve acil durum tatbikatlarından haberdar olduklarını belirtmişlerdir $(p<0.001)$. Çalışma süresi arttıkça tatbikatlardan haberdar olma yüzdesi de artmaktadır.

Katılımcıların çalıştığı hastanenin afet ve acil durumlara hazır olup olmadığını düşünmesi ile istatistiksel olarak ilişkili olan değişkenler ise, yaş, hemşire olarak çalışma süresi, çalıştığı pozisyon ve üniversite hastanesinde çalışma süresidir (sırasıyla: $p<0.001, p=0.001, p=0.029, p=0.03$ ).

Katılımcılardan çalıştığı hastanenin afet ve acil durumlara karşı hazır olduğunu düşünenlerin $(\% 39.3, n=156)$ yaş gruplarına göre dağılımı $21-30$ yaş $\% 44.2(n=69)$ ve $31-61$ yaş $\% 55.8$ ( $n=87)$ şeklindedir.

Hemşire olarak çalışma süresi ile afet ve acil durumlara hazır olduğunu düşünme arasında istatistiksel olarak anlamlı bir ilişki bulunmuştur $(p=0.001)$. Araştırmaya katılan hemşirelerden hastanenin afet ve acil durumlara hazır olduğunu düşünmeyenlerin en yoğun olduğu grup meslekte 0-5 yıl arası çalışmış olanlardır (\%53.7, $\mathrm{n}=130)$.

Çalıştığı pozisyon ile afet ve acil durumlara hazır olduğunu düşünme arasında da istatistiksel olarak anlamlı bir ilişki bulunmuştur ( $p=0.029)$. Başhemşirelerin \%58.6'sı, bölüm, poliklinik ya da servis hemşirelerinin ise \%38.0'i hastanenin afet ve acil durumlara hazır olduğunu düşünmektedir.

Araştırmaya katılan hemşirelerden üniversite hastanesinde 0-24 ay arası çalışanların \%28.4'ü $(n=21), 25$ ay ve yukarısı çalışanların ise \%42.0'si ( $n=137)$ hastanenin afet ve acil durumlara hazır olduğunu düşünmektedir $(p=0.03)$. 
Tablo 3. Üniversite Hastanesinde Çalışan Katılımcı Hemşirelerin Afet ve Acil Durumlar ile ilgili Deneyimleri ve Hastane Afet ve Acil Durum Planlarına Yönelik ifade ve Görüşleri ile i̇statistiksel Olarak Anlamlı iliş̧i Gösteren Değişkenler ( $\mathrm{n}=402$ )

\begin{tabular}{|c|c|c|c|c|c|}
\hline \multicolumn{6}{|c|}{ Afet ve acil durumla ilgili eğitim alma } \\
\hline & & Evet & Hayır & $\mathrm{X}^{2}$ & $\mathbf{p}$ \\
\hline \multirow[t]{2}{*}{ Yaş } & $21-30$ & $139(\% 62.6)$ & 83 (\%37.4) & \multirow[t]{2}{*}{16.778} & \multirow[t]{2}{*}{$<0.001$} \\
\hline & $31-61$ & $144(\% 81.4)$ & $33(\% 18.6)$ & & \\
\hline \multirow{3}{*}{$\begin{array}{l}\text { Hemşire olarak } \\
\text { çalışma süresi }\end{array}$} & $0-5 \mathrm{yıl}$ & $114(\% 61.6)$ & $71(\% 38.4)$ & \multirow[t]{3}{*}{14.914} & \multirow[t]{3}{*}{0.001} \\
\hline & $6-10 \mathrm{yıl}$ & $117(\% 80.7)$ & $28(\% 19.3)$ & & \\
\hline & 11 yıl ve üzeri & $53(\% 74.6)$ & $18(\% 25.4)$ & & \\
\hline \multirow{2}{*}{$\begin{array}{l}\text { Üniversite } \\
\text { hastanesinde } \\
\text { çalışma süresi }\end{array}$} & $0-24$ ay & $37(\% 49.3)$ & $38(\% 50.7)$ & \multirow[t]{2}{*}{20.775} & \multirow[t]{2}{*}{$<0.001$} \\
\hline & 25 ay ve üzeri & $248(\% 75.8)$ & $79(\% 24.2)$ & & \\
\hline \multicolumn{6}{|c|}{ Afet ve acil durumda görevli olarak çalışma } \\
\hline \multirow{3}{*}{$\begin{array}{l}\text { Çalıştı̆ı } \\
\text { pozisyon }\end{array}$} & & Evet & Hayır & $\mathrm{X}^{2}$ & p \\
\hline & Başhemşire & $5(\% 17.2)$ & $24(\% 82.8)$ & \multirow[t]{2}{*}{15.824} & \multirow[t]{2}{*}{$<0.001$} \\
\hline & $\begin{array}{l}\text { Bölüm, poliklinik } \\
\text { ya da servis hemşiresi }\end{array}$ & $10(\% 2.7)$ & $362(\% 97.3)$ & & \\
\hline \multirow{2}{*}{$\begin{array}{l}\text { Afet ya da } \\
\text { acil durum yaşama }\end{array}$} & $0-24$ ay & $10(\% 10.1)$ & 89 (\%89.9) & \multirow[t]{2}{*}{14.769} & \multirow[t]{2}{*}{$<0.001$} \\
\hline & 25 ay ve üzeri & $5(\% 1.7)$ & 297 (\%98.3) & & \\
\hline \multicolumn{6}{|c|}{ Hastane Afet ve Acil Durum Planlarından haberdar olma } \\
\hline & & Var & Yok & $\mathbf{X}^{2}$ & p \\
\hline \multirow[t]{2}{*}{ Yaş } & $21-30$ & $95(\% 42.8)$ & $127(\% 57.2)$ & \multirow[t]{2}{*}{47.924} & \multirow[t]{2}{*}{$<0.001$} \\
\hline & $31-61$ & $136(\% 77.3)$ & $40(\% 22.7)$ & & \\
\hline \multirow{3}{*}{$\begin{array}{l}\text { Hemşire olarak } \\
\text { çalışma süresi }\end{array}$} & $0-5 \mathrm{yıl}$ & $75(\% 40.5)$ & $110(\% 59.5)$ & \multirow[t]{3}{*}{46.266} & \multirow[t]{3}{*}{$<0.001$} \\
\hline & $6-10 \mathrm{yıl}$ & $104(\% 72.2)$ & $40(\% 27.8)$ & & \\
\hline & 11 yıl ve üzeri & $55(\% 77.5)$ & $16(\% 22.5)$ & & \\
\hline \multirow{2}{*}{$\begin{array}{l}\text { Afet ya da } \\
\text { acil durum yaşama }\end{array}$} & Evet & $76(\% 76.8)$ & $23(\% 23.2)$ & \multirow[t]{2}{*}{18.34} & $<0.001$ \\
\hline & Hayır & $158(\% 52.3)$ & $144(\% 47.7)$ & & \\
\hline Hastane Afet ve Acil Durc & ki görevini bilme & & & & \\
\hline & & Evet & Hayır & $\mathbf{X}^{2}$ & $\mathbf{p}$ \\
\hline Hemşire olarak & $0-5 \mathrm{yll}$ & $37(\% 46.8)$ & $42(\% 53.2)$ & 9.793 & 0.007 \\
\hline çalışma süresi & $6-10 \mathrm{yıl}$ & $62(\% 58.5)$ & $44(\% 41.5)$ & & \\
\hline & 11 yıl ve üzeri & $18(\% 32.7)$ & 37 (\%67.3) & & \\
\hline Üniversite hastanesinde & $0-24$ ay & $14(\% 33.3)$ & $28(\% 66.7)$ & 4.843 & 0.028 \\
\hline çalışma süresi & 25 ay ve üzeri & $103(\% 52.0)$ & $95(\% 48.0)$ & & \\
\hline Afet ve acil durum tatbik & erdar olma & & & & \\
\hline & & Evet & Hayır & $x^{2}$ & p \\
\hline Yaş & $21-30$ & $43(\% 42.6)$ & $58(\% 57.4)$ & 10.275 & 0.001 \\
\hline & $31-61$ & 87 (\%63.5) & $50(\% 36.5)$ & & \\
\hline Hemşire olarak & $0-5 \mathrm{yll}$ & 30 (\%37.5) & $50(\% 62.5)$ & 15.531 & $<0.001$ \\
\hline çalışma süresi & $6-10 \mathrm{yıl}$ & $64(\% 60.4)$ & $42(\% 39.6)$ & & \\
\hline & 11 yıl ve üzeri & $38(\% 69.1)$ & $17(\% 30.9)$ & & \\
\hline Üniversite hastanesinde & $0-24$ ay & $6(\% 14.0)$ & $37(\% 86.0)$ & 35.202 & $<0.001$ \\
\hline çalışma süresi & 25 ay ve üzeri & $126(\% 63.6)$ & $72(\% 36.4)$ & & \\
\hline
\end{tabular}


Tablo 3. Üniversite Hastanesinde Çalışan Katılımcı Hemşirelerin Afet ve Acil Durumlar ile ilgili Deneyimleri ve Hastane Afet ve Acil Durum Planlarına Yönelik ifade ve Görüşleri ile i̇statistiksel Olarak Anlamlı ilişki Gösteren Değişkenler ( $n=402)$ (devamı)

\begin{tabular}{|c|c|c|c|c|c|}
\hline \multicolumn{6}{|c|}{ Çalıştığı hastanenin afet ve acil duruma hazır olup olmadığını düşünme } \\
\hline & & Evet & Hayır & $\mathrm{X}^{2}$ & $\mathbf{p}$ \\
\hline \multirow[t]{2}{*}{ Yaş } & $21-30$ & $69(\% 31.2)$ & $152(\% 68,8)$ & \multirow[t]{2}{*}{13.62} & \multirow[t]{2}{*}{$<0.001$} \\
\hline & $31-61$ & $87(\% 49.4)$ & $89(\% 50.6)$ & & \\
\hline \multirow[t]{3}{*}{ Hemşire olarak çalışma süresi } & $0-5 \mathrm{yıl}$ & $55(\% 29.7)$ & $130(\% 70.3)$ & \multirow[t]{3}{*}{14.105} & \multirow[t]{3}{*}{0.001} \\
\hline & $6-10 \mathrm{yıl}$ & $71(\% 49.3)$ & $73(\% 50.7)$ & & \\
\hline & 11 yıl ve üzeri & $32(\% 45.1)$ & $39(\% 54.9)$ & & \\
\hline \multirow[b]{2}{*}{$\begin{array}{l}\text { Çalıştığı } \\
\text { Pozisyon }\end{array}$} & Başhemşire & $17(\% 58.6)$ & $12(\% 41.4)$ & \multirow[b]{2}{*}{4.783} & \multirow[b]{2}{*}{0.029} \\
\hline & $\begin{array}{l}\text { Bölüm, poliklinik ya da servis } \\
\text { hemşiresi }\end{array}$ & $141(\% 38.0)$ & $230(\% 62.0)$ & & \\
\hline \multirow{2}{*}{$\begin{array}{l}\text { Üniversite hastanesinde } \\
\text { çalışma süresi }\end{array}$} & $0-24$ ay & $21(\% 28.4)$ & $53(\% 71.6)$ & 4.7 & \multirow[b]{2}{*}{0.03} \\
\hline & 25 ay ve üzeri & $\begin{array}{l}137 \\
(\% 42.0)\end{array}$ & $\begin{array}{l}189 \\
(\% 58.0)\end{array}$ & & \\
\hline
\end{tabular}

$\mathrm{X}^{2}$ :Ki-kare testi 


\section{TARTIŞMA}

Araştırmanın yapıldığı üniversite hastanesi, birçok faklı hastaneden oluşan kompleks bir hastane yapılanmasıdır. Hastanenin büyüklügü ve ulaşılan hemşire sayısı göz önüne alındığında bu çalışmanın afet ve acil durum planları ile ilgili yapılan çalışmalara önemli katkılar sağlayacağı düşünülmektedir. Ancak, veri toplama araçlarının uygulanması başlığında da belirtildiği gibi bazı bölüm, poliklinik ya da servislerde toplam hemşire sayısı kadar değil, birim sorumlularının izin verdiği sayıda anket bırakılabilmiştir. Bu durum çalışmaya katılmak isteyebilecek bazı hemşirelerin katılımını sınırlandırmış olabilir.

Çalışmaya katılan hemşirelerin cinsiyetlerine bakıldığında kadın hemşire sayısının erkek hemşirelere göre oldukça yüksek olduğu gözlenmiştir (383 Kadın, 19 Erkek). Ülkemizin sağlıkla ilgili kuruluşlarında çalışan erkek hemşire sayısı sınırlıdır. Bunun sınırlı olmasının nedeninin ise, erkeklerin üniversitelerin hemşirelik bölümüne ancak yakın bir tarihten itibaren kaydolmaya başlamalarından dolayı ülkemizin sağlıkla ilgili kuruluşlarında çalışan erkek hemşire sayısının sınırlı olmasıdır. Benzer bir durumun araştırmanın yapıldığı üniversite hastanesi için de geçerli olduğunu düşünmekteyiz. Uzmanlık alanlarına göre değerlendirildiğinde, katılımcıların anketi yanıtlama yüzdesinin en düşük olduğu hastane onkoloji hastanesi, en yüksek olduğu hastane ise diğer hastane birimidir. Hemşirelerin anketi yanıtlama yüzdelerindeki farklılığın sebebinin hemşirelerin farklı iş yoğunluğu ve temposundan kaynaklandığı düşünülmektedir.

Üniversite hastanesinde çalışan hemşireler, uzmanlık alanı farklı olan 5 hastanede çalışmaktadırlar. Bu hastanelerde çalışan hemşirelerin sayısı hasta yoğunluğu, yatak kapasitesi vb. nedenlerle farklılık göstermektedir. Araştırmaya katılan hemşirelerin çalıştıkları hastaneye göre dağılımları oldukça farklıdır. Çalışmaya katılanlar arasında erişkin hastanesinde çalışan hemşire sayısı toplam hemşirelerin yarısını (\%53.7) oluşturmakta iken, diş hekimliğinde çalışan 5 (\%1.2) hemşire bulunmaktadır. Dağılımdaki düzensizlik her ne kadar hastanenin gerçek sayıları ile paralel ise de, uzmanlık alanlarına göre hastaneler arası karşılaştırma yapılmasına engel olmuştur.

Ayrıca üniversite hastanesinde çalışan ve araştırmaya katılmayı kabul eden hemşirelerin çoğunluğu bölüm, poliklinik ya da servis hemşiresidir (\%92.8, $n=373$ ). Eğitim, idari, başhemşire pozisyonlarında çalışan hemşire sayısı daha sınırlıdır. Hemşirelerin çalıştıkları birim ve pozisyona göre dağılımları homojen olmadığından, afet ve acil durumla ilgili karşılaştırmalarda ki kare anlamlılık testi uygulanamamıştır. Çalıştıkları hastaneye göre hemşirelerin yaş ve eğitim durumlarında önemli farklılıklar bulunmamaktadır.

Araştırmaya katılan hemşirelerin bu hastanedeki çalışma süresine bakıldığında 0-24 ay arası çalışanlar \%18.7'lik kısmı oluşturmaktadır. Neredeyse, çalışmaya katılan her beş hemşireden birisi yeni çalışmaya başlamıştır.

Çalışmaya katılan hemşirelerin çalıştıkları hastaneye göre çalışma süreleri incelendiğinde diğer hastane birimi ve diş hekimliğinde 11 yıl ve üzeri çalışan hemşire yüzdelerinin daha fazla olduğu görülmektedir. Genellikle 10 yıl çalışma süresinden sonra hastane yönetiminin hemşireleri sadece gündüz vardiyası olan birimlerde görevlendirmesinin bu dağılımın nedeni olabileceği düşünülmektedir.

Uzmanlık alanı 5 farklı hastanede çalışan hemşirelerin sayılarının farklı olmasından dolayı, hastane bazında çalışmaya katılım konusunda da homojen bir dağııı söz konusu değildir. Sayılardaki bu farklılıklar afet ve acil durum planları ile ilgili karşılaştırmalarda ki kare anlamlılık testi uygulanmasını engellemiştir.

Yapılan çalışmada ankete katılan hemşirelerin sadece \%48.8'i ( $n=117$ ) HAP'daki görevini bildiğini ifade etmiştir. Görevlerine ilişkin çoğunlukla hasta güvenliğini sağlamak, hasta transferini sağlamak ve koordinasyonu sağlamak şeklinde yanıtlar alınmıştır. Çakmak ve arkadaşlarının (2010) yaptığı bir çalışmada araştırmaya katılan hastane personelinin \%51.2'si HAP'daki görevini bildiği ifade etmiştir ${ }^{20}$. Bu bulgular bizim çalışmamızda elde ettiğimiz bulgularla paralellik göstermektedir.

Araştırmaya katılan hemşirelerin \%70.9'u $(n=282)$ afet ya da acil durumla ilgili eğitim aldığını belirtmişlerdir. Alınan eğitimlerin çoğunluğu ilk yardım ve yangın güvenliği eğitimi olarak belirtilmiştir. Hemşirelerin \%29.1'lik kısmı herhangi bir eğitim almadığını belirtmiştir. Eğitim almayanların büyük çoğunluğu meslekte 5 yılını doldurmamış ve 21-30 yaş aralığında olan hemşirelerdir. Buna bağı olarak çalışma süresi ve yaş artıkça eğitim alma düzeyleri de artmaktadır. Bu durum eğitimlerin bir sisteme göre verilmesinden ziyade zaman içerisinde bir şekilde hemşirelerin verilen eğitimlere katıldıkları, dolayısı ile yaş arttıkça bu kapsamdaki eğitimlere denk gelme şanslarının artması ile açıklanabilir. Bu çalışmadaki bulgularımızla Hammad'ın (2011) yaptığı ve 588 hemşireye ulaşılması planlanırken, 194 hemşireye ulaşılabilen çalışmanın bulguları paralellik göstermektedir (Hammad, 2011). Söz konusu araştırmada çalışma kapsamındaki hemşirelerin \%69.0'unun afet ve acil durum ile ilgili eğitim aldığı belirtilmiştir ${ }^{24}$.

Araştırmada katılımcıların \%25.0'i ( $n=104)$ daha önce herhangi bir afet ya da acil durum yaşadığını belirtmişlerdir. Afet ya da acil durum yaşayan hemşirelerin çoğunluğu (\%73.0) ise HAP'dan haberi olduğunu ifade etmiştir. Araştırma sonuçları, herhangi bir afet ve acil durum ile karşılaşan katılımcı hemşirelerin diğer katılımcı hemşirelere göre bu gibi durumlara karşı daha fazla farkındalıkları olabileceğini düşündürmektedir.

Araştırmaya katılanların \%3.0'ü $(n=15)$ herhangi bir afet ya da acil durumda görev aldığını belirtmişlerdir. Bunlardan çoğunluğu 1999 depreminde çalışmışlardır. Afette görevli olarak çalışanların önemli bir çoğunluğu (\%66.6) ise en az bir afet yaşadığını ifade etmişlerdir. Bu durum afet yaşamanın afette görevli olarak çalışma isteğini artırdığı veya afette görev aldıkları dönemde zaten afet yaşanan bölgede çalışıyor olabilecekleri ile açıklanabilir. Ancak elimizde bunu değerlendirecek bir veri mevcut değildir.

Araştırmaya katılanların \%59.0'u ( $n=240)$ HAP'la ilgili dokümanı gördüğünü belirtmişlerdir. Görülme yerlerine ilişkin soruya daha çok Nucleus Medikal Bilgi Sistemi ve çalıştıkları bölge olarak yanıtlar verilmiştir. Fakat bölüm, poliklinik ya da servislerde basılı olarak HAP dokümanı 
bulunmamaktadır. Hastanenin çeşitli yerlerinde asılı olan Hastane Acil Durum Haritasının, katılımcı hemşirelerin bir kısmınca HAP olarak algılandığı düşünülmektedir. Bu yanlış algının çalışmaya katılan hemşirelerin bir kısmının gördüklerini ifade ettikleri HAP'ın aslında araştırmanın yapıldığı üniversite hastanesinin çeşitli yerlerinde asılı olan Hastane Acil Durum Haritası olabileceğini düşündürmektedir. Bu durum hemşirelerin HAP konusunda yeterli bilgiye sahip olmadığının göstergelerindendir. Ancak, bu haritalar üzerine yazılabilecek ve daha detaylı bilginin nereden alınabileceğine ilişkin bir uyarı notu da belki bazı çalışanları daha kapsamlı incelemeye sevk edebilir.

"HAP ile ilgili eğitim ya da bilgilendirme yapıldı mı?" sorusuna hemşirelerin \%20.8'i $\quad(n=50)$ hayır ya da bilmiyorum yanıtını vermiştir. $\mathrm{Bu}$ durum, yapılan bilgilendirmelerin vardiya sistemiyle çalışan bütün hemşirelere ulaşabilmesi için yeterli sayıda ve şekilde tekrarlanmamış olmasından kaynaklanmış olabilir. Vatan ve arkadaşları (2010) İzmir'de 9 hastane ve 60 yönetici hemşire ile yaptığı çalışmada katılımcıların sadece \%56.0'sı HAP ile ilgili bilgilendirmenin yapıldığını belirtmiştir ${ }^{18}$. Bilgilendirme açısından hastaneler arası fark olabileceği beklenebilecek bir durumdur.

Başhemşirelerin \%58.6'sı, bölüm, poliklinik ya da servis hemşirelerinin ise \%35.3'ü hastanenin afet ve acil durumlara hazır olduğunu düşünmektedir.

Araştırmaya katılanlardan "Çalıştığınız hastane için afet ve acil durum oluşturabilecek tehlikeler nelerdir?" sorusuna deprem, sel, toprak kayması, salgın, kimyasal sızıntı, yangın ve patlama seçeneklerinden bir veya fazlasının işaretlenerek yanıtlaması istenmiştir. Elde edilen sonuçlarda göze çarpan ise hemşirelerin olası bir afet ya da acil durum olarak bütün ihtimalleri değerlendirerek yanıt vermiş olduklarıdır. Katılımcılar değişik düzeylerde de olsa bütün sayılan olayların hastane için bir tehlike oluşturduklarını düşünmektedirler.

"HAP'ı sizce hangi personel grubu hazırlamalı?" sorusu için sunulan seçeneklerde doktorlar, hemşireler, tüm sağlık personeli seçeneği de bulunmasına rağmen hemşireler çoğunlukla bütün personel grupları yanıtını seçmişlerdir. Ayrıca ankete verilen yanıtlarda sadece hemşireler yanıtını da seçen kimse olmamıştır. Verilen bu yanıtlar hemşirelerin, sadece sağlık çalışanlarının ya da bir grubun bu planı hazırlamasını doğru bulmadıkları şeklinde yorumlanabilir.

Araştırmaya katılanlardan "HAP'ın geliştirilmesi için en önemli öneriniz nedir?” sorusuna çoğunlukla eğitim ve tatbikat şeklinde yanıt vermişlerdir. Çağdaş öğrenme sistemi bize göstermektedir ki eğitim daha verimli olması için pratik ile desteklenmelidir. Elde edilen bulgulara göre katılımcı hemşireler de aynı yaklaşımla sadece teorik eğitimin yeterli olmadığını bunun tatbikatlarla güçlendirilmesi gerektiği görüşündedirler.

Oluşturulan çapraz tablodan elde edilen bulgulara göre hemşirelerin yaşları ile afet ya da acil durum ile ilgili eğitim alma durumları, HAP'dan ve tatbikatlardan haberdar olma ve çalıştıkları hastanenin afet ya da acil durumlara hazır olduğunu düşünme arasında ilişki olduğu görülmüştür. Yaş ilerledikçe eğitimlerden, duyurulardan ve tatbikatlardan haberdar olma yüzdeleri de artmaktadır.
Üniversite hastanesinde çalışma sürelerine bakıldığında, çalışma süresi arttıkça afet ya da acil durumla ilgili eğitim alma, HAP'daki görevini bilme, çalıştığı hastane afet ve acil durum tatbikatlarından haberi olma, çalıştığı hastanenin afet ve acil durumlara hazır olduğunu düşünme düzeyleri arasında doğru orantılı olarak artış söz konusudur. Bu durum, zaman içerisinde bir şekilde hemşirelerin eğitimlere, duyurulara ve tatbikatlara denk gelme olasılıklarının artmasıyla açıklanabilir.

Yaş ve çalışma süresinin, afet ya da acil durum ile ilgili eğitim alma, HAP'dan ve tatbikatlardan haberdar olma, HAP'daki görevini bilme, çalıştıkları hastanenin afet ya da acil durumlara hazır olduğunu düşünme düzeyleri arasında doğru bir orantı bulduğumuz çalışmamızda, hemşire olarak çalışma sürelerine baktığımızda, HAP'dan haberdar olma ve çalıştığı hastanenin afet ve acil durum tatbikatlarından haberdar olma düzeyleri sürekli bir artış gösterirken, afet ve acil durum ile ilgili eğitim alma, HAP'daki görevini bilme ve çalıştığı hastanenin afet ya da acil durumlara hazır olduğunu düşünme düzeyleri ise, 11 yıl ve üzeri çalışanlarda ise artış devam etmemektedir. Bazı çalışmalar kurumda çalışılan sürenin artmasıyla birlikte kuruma bağlığın da artabileceğini savunmaktadırlar ${ }^{25}$. Çalışmamızda kurum içindeki çalışmalardan haberdar olma konusunda bir artış söz konusu olmakla birlikte 11 yıldan sonraki ivme kaybını, "Kamu Çalışanlarının Örgütsel Bağılığı: Karşılaştırmalı Bir Çalışma" isimli araştırmanın açıklayabileceğini düşünmekteyiz. Bu çalışmada kurumsal bilgilerden haberdar olma konusunda en yüksek düzeylerin 6-10 yıl arasında çalışan hemşirelerde olduğu görülmüştür. Çalışma süresi 05 yıl olan hemşirelerin çalıştıkları kurumda kararsız oldukları ve çalışma süresi 11 yıl ve üzeri olanlarının ise kendini kuruma bağlı hissetmedikleri sonucuna ulaşılmıştır ${ }^{26}$. Çalışma sonucunda bu durum, çalışma yıllarına göre kuruma hâkimiyet ve kurum içindeki çalışmalardan ve etkinliklerden haberdar olma düzeylerinin farklılaşabileceği ile açıklanmıştır.

Başhemşirelerin \%58.6'sı, bölüm, poliklinik ya da servis hemşirelerinin ise \%35.3'ü hastanenin afet ve acil durumlara hazır olduğunu düşünmektedir. Bu durum başhemşirelerin yönetici pozisyonlarından kaynaklı olarak, hastane ile ilgili planlar konusunda daha iyi bilgilendirildikleri şeklinde yorumlanabileceği gibi, pozisyonları gereği negatif bir düşünce belirtmek istemeyebileceklerinden de kaynaklanmış olabilecekleri düşünülmektedir.

Üniversite hastanesinde çalışma süresi arttıkça afet ya da acil durumla ilgili eğitim alma, HAP'daki görevini bilme, tatbikatlardan haberdar olma gibi bazı değişkenlerin de yüzdesi artmaktadır. Bu ilişki, kurumda çalışılan sürenin artması ile kuruma hâkimiyetin artması ve kurum içindeki çalışmalardan ve etkinliklerden haberdar olma düzeyinin de artabileceği şeklinde açıklanabilir.

Yukarıda bahsedilmiş olan diğer karşılaştırmalarda da görüleceği gibi çalışma süresi arttığında hemşirelerin eğitimlere HAP'la ilgili bilgilendirmelere ve tatbikatlara maruz kalma olasılığı artmış, bunun sonucunda da çalıştıkları hastanenin afet ya da acil durumlara hazır olacağını düşünüyor olabilirler. 
Hemşirelerin herhangi bir afet ya da acil durum yaşamaları ile böylesi olaylarda çalışma durumları, HAP'dan haberdar olmaları arasında bir ilişki gözlenmiştir. Herhangi bir afet ya da acil durum yaşayanlar, yaşamayanlara göre bu gibi durumlara daha ilgili olabilecekleri söylenebilir. Yine herhangi bir afet ya da acil durum yaşayan hemşireler, yaşamayan hemşirelere kıyasla daha çok afet ya da acil durumda görevli olarak çalışmıştır. Bu durumun çalıştıkları birim veya üniversite hastanesinden önce çalıştıkları bölge ile de ilişkili olabileceği düşünülmektedir.

\section{SONUÇ ve ÖNERILER}

Hastane Afet ve Acil Durum Planları'ndan haberi olmadığını ya da bilmediğini ifade edenlerin yarısından fazlası genç hemşirelerden oluşmaktadır. Bu sonuçlara göre afet ve acil durumla ilgili eğitim verme, HAP ile ilgili farkındalık oluşturma, tatbikatlara dâhil edilme ya da kurumu benimsemeleri için girişimlerde bulunma konularında meslekte yeni hemşirelere öncelik verilebilir. HAP ile ilgili eğitimler meslek içi ve kurum içi eğitimlere dâhil edilerek genç hemşirelerin bu eğitimleri alabilmeleri sağlanmalıdır. $\mathrm{Bu}$ eğitimlerin uygulanması ise mesleğin ve kurumda çalışmanın ilk yıllarında daha yoğun ve daha sıkı olmalıdır. Katılımcıların HAP olarak bildiklerini ifade ettikleri, fakat gerçekte bir acil durum haritası olan basılı dokümanların üzerine yazılabilecek ve daha detaylı bilginin nereden alınabileceğine ilişkin bir uyarı notu da belki bazı çalışanları daha kapsamlı incelemeye sevk edebilir.

Katılımcılardan, HAP'ın geliştirilmesine dair en önemli önerileri çoğunlukla eğitim ve tatbikat şeklinde olmuştur. Yapılan tatbikatlar iyi değerlendirilerek başta hemşireler olmak üzere tüm personele duyurulmalı ve aktif katılımları sağlanmalıdır. Ayrıca hemşirelerin HAP'a ne kadar hâkim olduklarının ve bu konudaki objektif bilgilerin daha detaylı araştırmalar ile değerlendirilmesi önerilmektedir.

Etik Kurul Onayı: Bir üniversite hastanesinin Girişimsel Olmayan Klinik Araştırmalar Etik Kurulu'ndan izin alınmıştır (Karar No: GO 16/54-06).

Çıkar Çatışması: Bildirilmemiştir.

Finansal Destek: Yoktur.

Katılımcı Onamı: Hemşirelerden bilgilendirilmiş onam

alınmıştır.

Yazar katkıları:

Araştırma dizaynı: Ai, STY

Veri toplama: Ai

Veri analizi: Ai, STY

Makale yazımı: Ai, STY

Teşekkür

Çalışmaya katılan tüm hemşirelere teşekkür ederiz.

Ethics Committee Approval: Permission was obtained from the Non-Interventional Clinical Research Ethics Committee of a university hospital (Decision Number: GO 16/54-06).

Confict of Interest: Not reported.

Funding: None.

Exhibitor Consent: Informed consent was obtained from nurses.

\section{Author contributions:}

Study design: Ai, STY

Data collection: Ai

Data analyses: Ai, STY

Drafting manuscript: Ai, STY

Acknowledgement: We would like to thank all nurses who participated to the study.

\section{KAYNAKLAR}

1. Ünal $Y$, Işık E, Şahin S, Tekel Yeşil S. Sağlık Afet çalışanlarının depremlere ilişkin bireysel hazırlık düzeylerinin değerlendirilmesi: Ulusal Medikal Kurtarma Ekipleri (UMKE) Derneği örneği. DEÜ Tıp Fakültesi Dergisi. 2017;31(2):71-80.

2. Tekeli Yeşil S, Afetlerin Halk Sağlığına Etkileri ve Afet Epidemiyolojisi. Kuş G, Tekin, N, editörler. Afet Tıbbı ve Yönetim İlkeleri Anadolu Üniversitesi. Eskişehir: Anadolu Üniversitesi Yayınları; 2017.

3. Tekeli Yeşil S. Sağıı Afet ve Acil Durum Planlarında Genel Yaklaşımlar ve Ülkemizde Kullanılan Planlar. Turk J Public Health 2017;15(3):233-44.

4. Tekeli Yeşil S. Public health and natural disasters: disaster preparednessand response in health systems. Journal of Public Health. 2006;14:317-24.

5. Tekeli Yeşil S,. Yerel Düzey Sağlık Afet ve Acil Durum Planları. Pampal S. editör. Acil Durum ve Afet Yönetimi Planları İlkeleri Anadolu Üniversitesi. Eskişehir: Anadolu Üniversitesi Yayınları; 2018.

6. İL-SAP, il Sağlık Afet ve Acil Durum Planları Hazırlama Kılavuzu T.C Sağlık Bakanlığı Bakanlık Yayın No:890 ISBN:978-975-590-438-2, 2012.

7. HAP, Hastane Afet ve Acil Durum Planı Hazırlama Kılavuzu, T.C Sağıık Bakanlığı Yayın No:1020 ISBN:978975-590-590-7, 2015.

8. Demirbaş H, Sezer A, Ergun A. Afet Yönetiminde Halk Sağlığı Hemşiresinin Rol ve Sorumlulukları. Florence Nightingale Hemşirelik Dergisi. 2013;21(2): 122-8.

9. Özpulat F, Kabasakal E. Knowledge Levels of Nursing Students on Disaster Nursing and Their State of Disaster Preparedness. International Journal of Medical Research \& Health Sciences. 2018;(8):165-174.

10. Ahayalimudin N, Ismail A, Saibon MI. Disaster management: a study on knowledge, attitude and practice of emergency nurse and community health nurse. BMC Public Health. 2012;12(2):A3.

11. Baack S. Analysis of Texas Nurses' Preparedness and Perceived Competence in Managing Disasters [PhD thesis]. Texas: The University of Texas; 2011.

12. Chapman K, Arbon P. Are nurses ready? Disaster preparedness in the acute setting. Emergency Nursing Journal. 2008;11(3):135-44.

13. Hammad KS, Arbon $P$, Gebbie K, Hutton A. Nursing in the emergency department (ED) during a disaster: $A$ review of the current literature. Australasian Emergency Nursing Journal. 2012;15(4):235-44.

14. Marin SM, Witt RR. Hospital nurses' competencies in disaster situations: a qualitative study in the south of Brazil. Hospital nurses' competencies in disaster 
situations: a qualitative study in the south of Brazil. Prehospital and Disaster Medicine-Cambridge Journals. 2015;30(6):1-5.

15. Fung WMO, Loke AY, Lai, CKY. Disaster preparedness among Hong Kong nurses. Journal of Advanced Nursing. 2008;62(6):698-703.

16. Thobaity AA, Plummer V, Innes K, Copnell B. Perceptions of Knowledge of Disaster Management among Military and Civilian Nurses in Saudi Arabia. Australasian Emergency Nursing Journal. 2015;18(3):156-64.

17. Elazeem HA, Adam S, Mohamed G. Awareness of Hospital Internal Disaster Management Plan among Health Team Members in an University Hospital. Life Science Journal. 2011;8(2):42-52.

18. Vatan F, Salur D. Yönetici Hemşirelerin Hastanelerdeki Deprem Afet Planları Konusundaki Görüşlerinin İncelenmesi. Maltepe Üniversitesi Hemşirelik Bilim ve Sanatı Dergisi. 2010;3(1):32-44.

19. Yurdakul A, Piroğlu F, Okay N. Kocaeli Derince Eğitim ve Araştırma Hastanesi Mevcut Afet Planı Çerçevesinde, Çalışanların Afete Hazırlığının Değerlendirilmesi. Mehmet Akif Ersoy Üniversitesi Sağlık Bilimleri Enstitüsü Dergisi. 2013;1(2):75-85.

20. Çakmak H, Aydın Er R, Can Öz Y, Aker AT. Kocaeli ili 112 Acil Yardım Birimlerinde Çalışan Personelin Marmara Depreminden Etkilenme ve Olası Afete Hazırlık Durumunun Saptanması. Akademik Acil Tıp Dergisi. 2010;2:83-88.

21. Türk Tabipleri Birliği. Hekimlerin Çalıştıkları Yataklı Tedavi Kurumlarının Olağandışı Durumlara Yönelik Hazırlıklılığını Değerlendirmeleri Araştırması. Ankara: Türk Tabipler Birliği Yayınları; 2009.

22. Demir T, Güney Akdeniz S, Karaca M. Hacettepe Üniversitesi Hastaneleri Hastane Afet ve Acil Durum Planı. Hacettepe Üniversitesi Yayınlanmamış iç Doküman. 2014.

23. Hacettepe Üniversitesi Sağlık Ekonomisi ve Sağlık Politikası Araştırma ve Uygulama Merkezi [internet]. 2018 [Erişim Tarihi 3 Eylül 2019]. Erişim adresi: http://www.husespam.hacettepe.edu.tr/.

24. Hammad KS, Arbon P, Gebbie KM. Emergency Nurses and Disaster Response: An Exploration of South Australian Emergency Nurses' Knowledge and Perceptions of Their Roles in Disaster Response. Australasian Emergency Nursing Journal. 2011;14(8):87-94.

25. Duygulu S, Abaan S. Örgütsel Bağlılık: Çalışanların Kurumda Kalma ya da Kurumdan Ayrılma Kararının Bir Belirleyicisi. Hacettepe Üniversitesi Hemşirelik Fakültesi Dergisi. 2007;14(2):61-73.

26. Sevinç İ, Şahin A. Kamu Çalışanlarının Örgütsel Bağlıı̆̆ı: Karşılaştırımalı Bir Çalışma. Maliye Dergisi. 2012;162:266-81. 